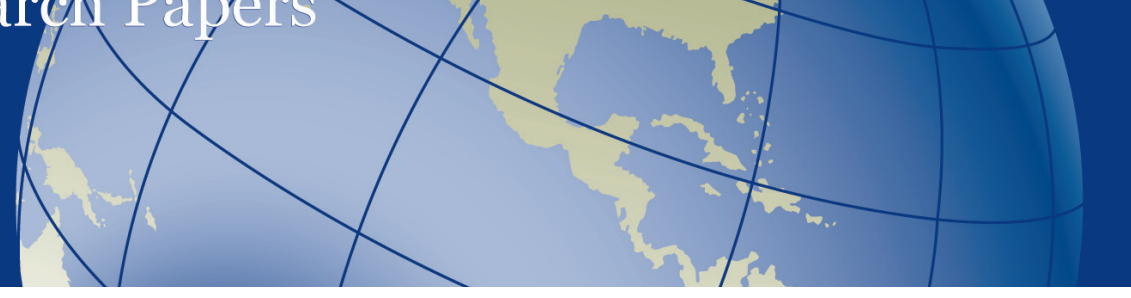

Volume 7 - Issue 17 • July 2014

\title{
WHO, OR WHAT, IS TO BLAME FOR THE ACCUMULATION OF DEBT IN ONTARIO AND QUEBEC (AND WHAT WILL IT TAKE TO STOP THE BLEEDING?) ${ }^{\dagger}$
}

Ron Kneebone and Margarita Wilkins

The School of Public Policy

\section{SUMMARY}

What is the main reason for government debt accumulation in Canada? Is the main driver of debt the public policy choices made by governments, or are non-policy factors, like interest rates and the economic environment to blame? Answering this question is the first step for governments burdened by high levels of government debt to introduce policies aimed at getting that debt under control.

The effort to curtail debts in the mid-1990s prompted research into the sources of debt accumulation. The goal of this research was to determine whether the cause of debt was a set of poor fiscal policy choices in the form of overly generous social programs and/or insufficient taxation, an overly tight monetary policy driving up interest costs on existing debt and slowing growth, or simply bad luck in the form of unavoidable world events. That research aspired to identify the sources of debt accumulation so those mistakes, once identified, might be avoided in the future.

This paper looks at Ontario and Quebec; two provinces with high and growing debt to GDP ratios and representing the two largest provincial economies in Canada. Introducing an original data set describing the finances of these governments over the period 1980-81 to 2011-12 and a new approach for identifying the causes of debt accumulation, this paper finds that the causes are disproportionate policy based. Finally, this paper offers a way out of debt for these governments. The solutions demand difficult policy choices; choices that will require a significantly heavier burden be borne by the citizens and taxpayers of Ontario than those in Quebec.

The authors wish to acknowledge the helpful comments of two anonymous referees and those of our colleague Bev Dahlby. We remain responsible for any errors or omissions. 


\section{INTRODUCTION}

Concern over public sector debts tends to wax and wane in Canada. After 30 years of falling debt-to-GDP ratios following WWII, debt ratios increased rapidly over the next 20 years, peaking in the mid-1990s. At that time, governments halted the growth of debt ratios, and put them on a downward path, with large and often controversial cuts to program expenditures and increases in tax rates. After a decade of falling levels of public debt - a period during which analysts debated whether the battle over public debt had been won ${ }^{l}-$ debt ratios have again moved upward. Memories of the price Canadians paid in the past when their governments had accumulated too much debt, like slower economic growth, higher interest rates, higher tax rates and cuts to social programs, are stoking recent concerns that these costs might need to be paid yet again.

The effort to curtail debts in the mid-1990s prompted research into the sources of debt accumulation. The goal of this research was to determine whether the cause of debt was a set of poor fiscal policy choices in the form of overly generous social programs and/or insufficient taxation, an overly tight monetary policy driving up interest costs on existing debt and slowing growth, or simply bad luck in the form of unavoidable world events. That research aspired to identify the sources of debt accumulation so those mistakes, once identified, might be avoided in the future.

Prominent in this debate was research by Pierre Fortin ${ }^{2}$ who used the arithmetic of the government budget constraint to isolate factors that can lead to an increase in a government's debt-to-output ratio. Applying his approach to data describing the federal government's budget, Fortin concluded that the structure of federal government programs played no part in the debt explosion and fingers should be pointed instead at the interest rate policies of the Bank of Canada for being ultimately responsible for the accumulation of federal government debt. ${ }^{3}$

In an effort to sharpen understanding of the issues, Ron Kneebone and Jack Leach ${ }^{4}$ investigated the significance of Fortin's assumptions and offered a different interpretation of the causes of debt accumulation. Their conclusion, namely that fiscal policy choices and changes due to the business cycle were equally responsible for the run-up of the federal debt-to-output ratio, stood in sharp contrast to Fortin's claims that fiscal policy choices should not be held responsible at all.

I See Is the Debt War Over? Dispatches from Canada's Fiscal Frontline, Christopher Ragan and William Watson (eds), McGill-Queen's University Press, 2004.

2 See Pierre Fortin, "The Canadian Fiscal Problem: The Macroeconomic Connection," in Pierre Fortin and Lars Osberg, eds., Unnecessary Debts, ed. P. Fortin and L. Osberg (Toronto: Lorimer), 1996. Also see Fortin's "The Great Canadian Slump," Canadian Journal of Economics 29(4):761 - 87, 1996 and "The Canadian Standard of Living: Is There a Way Up?" C.D. Howe Institute Benefactors Lecture 1999.

2 These claims in turn prompted a response from analysts with the Bank of Canada claiming biases in Fortin's approach that placed too much blame on the central bank. See Charles Freedman and Tiff Macklem, "A Comment on 'The Great Canadian Slump'," Canadian Journal of Economics 31(3):646 - 65, 1998. Fortin's conclusions were cited by those who argued that adjustments to social programs should not, therefore, be part of the effort at debt reduction. See for example, Linda McQuaig, Shooting the Hippo (Toronto: Penguin Books Canada), 1996.

4 Ronald Kneebone and John Leach, "The Accumulation of Public Debt in Canada," Canadian Public Policy, Volume 27, No. 3, September 2001. 
In this paper we revisit this debate in two ways. First, we offer what we consider to be a better measure of the amount of debt that can be deemed the responsibility of policy makers as opposed to external forces beyond their control. Second, we bring the debate to the level of individual provinces. ${ }^{5}$

Understanding the sources of debt accumulation at the provincial level is at least as important as understanding the issue at the federal level. Provincial governments in Canada control about 40 per cent of all government program spending, thus provincial debt accumulation is as much a concern as debt accumulation at the federal level. Moreover, the expenditure obligations of provincial governments - particularly in the realm of health care - are such that in future they face a far greater challenge to controlling levels of debt than does the federal government. Finally, whereas government debt at the federal level is falling as a fraction of GDP, the opposite is currently true at the provincial level. Identifying the reasons behind the recent growth in provincial government debt is therefore timely.

This paper will also contribute to the broader literature examining provincial budgets by providing a data-set describing the finances of individual provinces for the period from 198081 to 2012-13. As we explain in the next section of this paper, Statistics Canada has halted, with data spanning the period 1988-89 to 2008-09, the publication of its Financial Management System (FMS) data series describing details of provincial government finances. If, or until, this data series is continued, analysts have nothing to measure the influence on provincial government finances of the 2008-09 recession, the following recovery or the implications of the 1981-82 recession and the period of strong economic growth that followed up to 1989. Our data set rectifies these shortcomings of the more limited FMS data series.

This is the first of a series of reports on the public finances of Canadian provinces. This report uses public accounts data for the period 1980-81 to 2011-12 to summarize, describe and analyze the finances of the governments of Ontario and Quebec; those provinces with the most diversified and manufacturing-reliant economies. Future reports will apply this approach to the other provinces according to their most important economic characteristics. Relying on the simple arithmetic of debt accumulation implied by the government budget constraint, the sources of debt accumulation are identified, and inform a discussion of how much of the change in provincial debt can be laid at the feet of policy choices as opposed to economic conditions.

\section{THE DATA}

Out of fear it may bore the reader, it is not generally good form to include a discussion of the data in the body of a research paper. For this project, however, the construction of the dataset is central, and therefore worthy of elaboration.

Information on provincial government finances comes from provincial public accounts. These data employ accounting standards and approaches that differ across provinces and which change over time. These data can be used in the form they are reported or they can be used after certain modifications have been made to make them somewhat more comparable over time and across provinces. Both approaches involve challenges.

\footnotetext{
5 Kneebone and Leach took a step in this direction but only looked at the budgets of all provinces in aggregate.
} 
Statistics Canada's Financial Management System (FMS) attempts to make certain modifications to public accounts data. While the FMS data imposes a certain degree of uniformity on the public accounts data published by each province, Statistics Canada notes that this effort can never be complete. ${ }^{6}$ Moreover, the advantage of using data that imposes some degree of uniformity on public accounts data is offset by certain drawbacks to the accounting conventions FMS employs. In particular, the royalty revenue that provincial governments collect from the sale of natural resources is not reported separately in the FMS data. Rather, these revenues are included in the category of "investment income" and so, cannot be distinguished from the income provincial governments earn from financial assets and other sorts of investments. This is problematic given the importance of royalty income for many provinces and given the unique determinants of royalty income from other investment returns. The usefulness of FMS data is also severely limited by the fact that the information they provide on provincial finances start only in 1988-98 and end in 2008-09. ${ }^{7}$ Understanding the evolution of provincial government debt accumulation is enhanced by having a dataset describing a longer period of time.

Another source of information on provincial government finances is available from Statistic Canada's Provincial Economic Accounts (PEA). These data differ from the FMS data by reporting on a calendar, rather than fiscal year basis and by reporting on different aggregates of provincial finances. Thus, while the FMS data report provincial spending on functional categories such as health, education and social services, the PEA data report on the much broader category of "net current expenditures on goods and services." As part of the goal of this paper is to identify the implications of debt reduction on spending on items like health and education, the PEA data is less useful. Like the FMS data, the PEA data set is also limited by having been terminated by Statistics Canada - with the last year of data being provided was $2009 .^{8}$

The dataset we have constructed uses data as reported in provincial public accounts without any attempt at enforcing uniformity of accounting practices across provinces. ${ }^{9}$ While this reduces the ability to make provincial comparisons, it gains the ability to treat natural resource revenues (royalties) differently from other sources of investment income and, most importantly, enables the construction of a dataset that spans any period described by public accounts.

6 For a discussion, see Financial Management System (FMS), Statistics Canada, 2009, http://www.statcan.gc.ca/pub/68f0023x/68f0023x2006001-eng.pdf).

7 Statistics Canada is moving to a new approach to measuring government financial statistics and has indicated that it intends to soon begin publishing data based on its new accounting framework starting with fiscal year 2008-09. We are not aware of any statement suggesting that a revision to historical data will accompany the adoption of the new accounting framework.

8 On the revenue side, the PEA does allow a reasonably close comparison to our data for certain revenue categories. Thus, the PEA reports, for calendar years 1981-2009, the amount of direct taxes collected from persons by provincial governments; a data series that is closely comparable to our data on personal income tax collected. After making a rough adjustment to these calendar year data to allow a comparison to our fiscal year data we find the two sets of data have a 98 per cent correlation and that on average our data is equal to 96 per cent of the data reported in the PEA.

9 The Appendix presents our data on provincial government revenues and expenditures as reported in public accounts. Simply collecting these data proved challenging. We enthusiastically add our voices to the complaint recently expressed by Colin Busby and William Robson over the lack of transparency and consistency in provincial government financial accounting. See "Credibility on the (Bottom) Line: The Fiscal Accountability of Canada's Senior Governments, 2013,” Commentary No. 404, C.D. Howe Institute, March 2014. 
This paper focuses on the period from $1980-81$ to $2011-12 .{ }^{10}$ This enables the analysis to capture the effects on provincial finances of the 1980-81 recession, the strong period of economic growth prior to 1990, and the impact on provincial finances of the economic recovery since the end of the 2008-09 recession; influences on provincial finances that could not be studied at all using FMS data or fully studied using PEA data.

It is worth noting that the Fiscal Reference Tables (FRT) published by the federal Department of Finance also present data from provincial public accounts and largely adopts the practice of not trying to enforce uniformity in provincial accounting. The FRT, however, do not offer a breakdown of total spending and total revenue into sub-categories. Thus, to obtain data on revenue collected by provincial governments by type - personal and corporate income taxes, etcetera - and to determine program spending by program - health, education, etcetera one must go directly to the public accounts of individual provinces. Accessing this finer gradation of spending and revenue is important to understanding the sources of revenue and spending changes and is also important for identifying, as is done below, what portions of revenue and spending changes are due to the business cycle as opposed to policy choices.

It is important to emphasize that the focus of this study is only on that portion of provincial budgets referred to as the "operations account" (in Ontario) and the "general fund" (in Quebec); what will be referred to here as the government's operating account. The budgetary and debt implication of extraordinary public infrastructure investments is ignored. Thus, data for Quebec does not include the implications for the provincial government's net debt of the Generations Fund, Special Funds, and extraordinary losses such as those associated with the recent closing of the Gentilly nuclear plant. Similarly, in Ontario, we ignore extraordinary adjustments to net debt caused by, for example, the $\$ 20.9$ billion of debt absorbed by the government in 1999-2000 to facilitate the privatization of Ontario Hydro. ${ }^{11}$

The accumulation over time of deficits in the operating account defines what is referred to as the accumulated deficit. ${ }^{12}$ The government of Quebec is quite explicit about the meaning of the debt representing the accumulation of deficits on the operating account;

It represents the government's "bad debt", i.e., the debt that does not correspond to an asset, financial or non financial. It is often said that this is the debt incurred to "pay for the groceries". ${ }^{13}$

\footnotetext{
10 As described below our approach involves ratios of debt to GDP. The choice of time span therefore reflects in part the availability of a consistent data series on provincial GDP. Calendar year values of provincial GDP are available for the period 1980 to 2012 (sources are provided below). Data for 2013 are required - but not yet available - to use budget data for fiscal year 2012-13.

11 The $\$ 20.9$ billion figure is reported in Public Services for Ontarians: A Path to Sustainability and Excellence, a report of the Commission on the Reform of Ontario's Public Services (http://www.fin.gov.on.ca/en/reformcommission/). The report is more popularly known as the Drummond Report named after Don Drummond, Chair of the Commission.

12 These governments report a measure they refer to as the accumulated deficit. Those measures differ from ours by including adjustments involving other than the operating account (the general fund in Quebec and the operations account in Ontario). In Ontario, for example, the government figure includes consideration of non-financial assets in the broader public sector while in Quebec the government figure includes additions to and subtractions from a stabilization fund.

13 See Finances et Économie Québec, http://www.finances.gouv.qc.ca/en/page.asp?sectn=36\&contn=329
} 
The ratio of accumulated deficits to GDP stands in contrast to what governments report as their $n e t d e b t$, a measure that includes in its calculation the implications of extraordinary additions to debt of the sort referred to above. Net debt, then, represents a broader definition of the government's debt than the accumulated borrowing required to "pay for the groceries."

Between 1980-81 and 2011-12, accumulated deficits increased by $\$ 142.1$ billion in Ontario and $\$ 85.4 b i l l i o n$ in Quebec (all figures measured in nominal dollars). This is the increase in debt which we try to explain in this paper. Over that same period, net debt increased by $\$ 223.6$ billion in Ontario and by $\$ 152.8$ billion in Quebec. The difference in the change in net debt and the change in accumulated deficits - $\$ 81.5$ billion in Ontario and $\$ 67.4$ billion in Quebec is the accumulation of net debt since 1980-81 that has been the result of extraordinary expenditures outside of the operating account. No effort is made to explain this portion of the total increase in provincial debt. ${ }^{14}$

\section{THE SOURCES OF DEBT ACCUMULATION}

Households are constrained in their spending choices by their incomes and by what they are able to borrow. This simple fact of life has the important implication that the choices available to households are constrained by the economic environment in which they operate. A household facing high interest rates for borrowing and slow income growth is more limited in its spending choices than when interest rates are low and income is growing rapidly. A household that fails to adjust its spending when interest rates rise and income shrinks soon finds itself in financial trouble. In a nutshell, this is the reasoning behind the approach employed in this study to identify what portion of provincial government debt can be identified as due to policy choices as opposed to economic conditions.

The following equation defines a budget constraint for a government's current account balance:

$D_{t}-D_{t-1}=P D E F_{t}+r_{t} D_{t-1}$

where we define

$P D E F_{t}=$ primary deficit (program spending less current account revenue) in year $t^{15}$

$D_{t-1}=$ accumulated deficit of the current account at beginning of year $t$

$D_{t}=$ accumulated deficit of the current account at end of year $t$

$r_{t}=$ average interest rate on net debt in year $t$.

14 The Appendix reports levels of net debt and accumulated deficits by fiscal year. Constructing an accumulated deficit series required an initial value for the first year (1980-81) in this dataset. In Ontario, government accounts do not distinguish between net debt and accumulated deficits until 2002-03. It is assumed, therefore, that in 1980-81, the accumulated deficit was equal to net debt. In Quebec, that government's measure of the accumulated deficit for 1980-81 was used, as is reported in Table 16 of Historical Data, Budget 2012-2013, Finances Québec. Throughout this paper the emphasis is on explaining the change in the accumulated deficit and so the starting value is not critical.

15 The primary deficit can take on a negative or a positive value. If program spending is less than tax revenue the primary deficit has a negative value and may be referred to as a primary surplus. Program spending includes all government spending except debt service which is represented here as $r_{t} D_{t-1}$. At the provincial level of government the largest programs are health, education and social services. 
Some elements of the program spending and revenue in the current account are sensitive to the state of the economy (the business cycle). To account for these cyclical influences, one can write;

$D_{t}-D_{t-1}=\left(P D E F_{t}-P D E F_{t}^{*}\right)+P D E F_{t}^{*}+r_{t} D_{t-1}$

where $P D E F^{*}$ defines the cyclically-adjusted primary deficit and the term in brackets defines the size of the primary deficit that is due to the business cycle.

Of interest is the identification of sources of change in the ratio of the accumulated deficit to GDP, referred to more simply as the debt ratio. It makes sense to compare debt to GDP as the latter defines the collective income of the province's citizens, and so, measures the capacity for managing debt. Of interest, then, is explaining movements in;

$\frac{D_{t}}{Y_{t}}-\frac{D_{t-1}}{Y_{t-1}}$

where $Y$ is GDP. Using equation (1) and noting that values of $Y_{t}$ and $Y_{t-1}$ are related by the rate of growth in GDP in the following way;

$Y t=\left(1+\left(n_{t}-n_{t}^{*}\right)+n_{t}^{*}\right) Y_{t-1}$

where

$n=$ the rate of growth in $Y$

$n^{*}=$ the rate of growth in potential output, $Y^{*}$,

the change in the debt ratio can be written as;

$\frac{D_{t}}{Y_{t}}-\frac{D_{t-1}}{Y_{t-1}}=\left(\frac{P D E F_{t}}{Y_{t}}-\frac{P D E F_{t}^{*}}{Y_{t}}-\frac{\left(n_{t}-n_{t}^{*}\right) D_{t-1}}{Y_{t}}\right)+\left[\frac{P D E F_{t}^{*}}{Y_{t}}+\frac{\left(r_{t}-n_{t}^{*}\right) D_{t-1}}{Y_{t}}\right]$

The term in round brackets defines the cyclical component. It identifies the change in the debt ratio that is due to the economy being away from potential (or full employment) output and experiencing a rate of growth that differs from the rate of growth in potential output. The term in square brackets defines the policy component. It identifies the change in the debt ratio that is due to fiscal policy choices. ${ }^{16}$

${ }^{16}$ In the equation, the growth and interest rates are either nominal rates or real rates, but in the latter case, the interest rate must be the ex post real interest rate. It is worth noting that no attempt is made to identify how the interest rate might vary with the business cycle. This reflects an assumption that the interest rate does not react automatically to, or in a predictable way with, the business cycle. 


\section{Discussion}

The accounting used to identify that part of the annual change in the debt ratio due to the economic cycle (the cyclical component) versus that which is due to fiscal policy choices (the policy component) differs from that used in the literature. The approach used here is most closely akin to that defended by Kneebone and Leach. ${ }^{17}$ It differs by the inclusion of the last term defining the cyclical component. This consideration is important for explaining the change in the ratio of debt to GDP, since an economic slowdown affects not only the numerator by causing change in income-sensitive components of the primary deficit - and so, causes a gap between $P D E F$ and $P D E F^{*}$ - but also influences GDP itself - and so, causes a gap between the observed rate of growth in GDP, $n$, and the rate of growth in potential output, $n^{*}$.

The measure of the cyclical component used here is based on the simple observation that because some components of provincial program spending (such as social assistance payments) and income sensitive tax revenues rise and fall with the level of output, and since the level of GDP varies with the business cycle, then the ratio of debt to GDP will be sensitive to the state of the economy. Accusing a government of fiscal irresponsibility when its debt ratio is made large by the effects of recession is not fair. As such, this measure of the cyclical component identifies the change in the debt ratio due to the state of the economy, and so, identifies changes not considered grounds for criticism of fiscal policy choices.

It is important to stress that while the first term on the right hand side of equation (2) is labelled the cyclical component, its size is not "policy free". Its magnitude is affected by the extent to which governments make their revenues and spending obligations sensitive to changes in income. The cyclical component, then, shows the change in the debt ratio due to the business cycle impacting the government budget via the current set of tax rates and the current design of spending programs. Movements in the cyclical component, then, reflect the operation of automatic stabilizers the size of which is a matter of policy.

The measure of the policy component is motivated by the idea that fiscal policy choices are constrained by the level of debt inherited from previous governments and by the economic conditions determining the interest rate paid on outstanding debt, the rate of growth in the tax base and the levels of cyclically-sensitive spending and revenues. Depending on economic circumstances - particularly those determining the relative values of the interest rate due on outstanding debt and the rate of growth in potential output - the same set of fiscal policy choices reflected in the value of the cyclically-adjusted primary deficit $P D E F^{*}$ may or may not be labelled fiscally irresponsible.

To better appreciate this point, it is easy to see from the definition of the policy component that if the levels and growth rates of actual and potential output are equal, there is no tendency for the debt-to-output ratio to rise only if:

$P D E F_{t}^{*}=\left(n_{t}^{*}-r_{t}\right) D_{t-1}$

The term on the right-hand side is our preferred target for a fiscally responsible set of fiscal policy choices. The debt-to-output ratio will tend to rise as a consequence of fiscal policy choices when $P D E F_{t}^{*}$ is above the target, and tend to fall when $P D E F_{t}^{*}$ is below the target.

17 "The Accumulation of Public Debt in Canada." 
As noted by Kneebone and Leach, implicit in this argument is the idea that requiring the cyclically-adjusted primary deficit, $P D E F^{*}$, to be zero is not a very good measure of fiscal probity. ${ }^{18}$ Governments with outstanding debt cannot spend as if they were not responsible for paying the interest on the outstanding debt they have inherited. Their cyclically-adjusted primary deficits can be positive when the interest rate is low and the rate of growth in potential output is high $\left(r<n^{*}\right)$, but they should be negative when the interest rate is high and the rate of growth in potential output is low $\left(r>n^{*}\right)$.

When, as has often been the case since the 1980's, governments operate in a high interest rate, low growth environment, establishing a zero value for the cyclically-adjusted primary deficit is clearly irresponsible and is not a sign of fiscal probity. In this economic environment, the government's objective should be to operate with cyclically-adjusted primary surpluses and so offset the effect on the debt ratio of operating in a low growth - high interest rate environment.

In what follows, the definitions of the cyclical and policy components are applied to the data defining the government's operating account. It is useful to emphasize our focus on the operating account because it adds credence to the definition of the policy component. That is, the idea behind governments defining an operating account is to emphasize that the revenues in that account are to be used to pay for current spending (or "paying for the groceries"). The socalled "golden rule" of public finance is that operating accounts ought to be such that, in the normal course of events, they balance spending with revenues. In other words, the application of the golden rule is that at full employment the operating account should not be causing the debt ratio to increase. Applying the golden rule of public finance would require that, our definition of the policy component be zero at full employment, and that over time, when economic downturns have been balanced by economic booms, the accumulated deficits of the government's operating account should be zero.

\section{POTENTIAL OUTPUT AND THE CYCLICALLY-ADJUSTED PRIMARY DEFICIT}

The accounting framework requires that one identify cyclically adjusted provincial revenue and spending and use these values to define the cyclically-adjusted primary deficit, $P D E F^{*}$. This, in turn, requires estimates of potential output, $Y^{*}$, and its rate of growth, $n^{*}$.

It is common practice to generate values of provincial potential $\operatorname{GDP}\left(Y^{*}\right)$ by applying the Hodrick-Prescott filter to observed values of $\operatorname{GDP}(Y)$. The HP filter is intended to decompose data on GDP into trend and cycle components. ${ }^{19}$ The attraction of the HP filter is that its

18 Kneebone and Leach note that one might argue that setting $P D E F^{*}=0$ is a sensible target for fiscal responsibility if a long enough time horizon is chosen. That is, a government that equates cyclically-adjusted program spending with revenue has a neutral impact on the debt-to-output ratio if, over a period of time, the average value of the term on the right hand side of equation (3) is zero. Canada's experience in this regard is the same as that of many western economies: The Second World War was followed by a quarter century in which growth rates exceeded interest rates and then a quarter century in which interest rates exceeded growth rates. A policymaker would need a very long planning horizon before fiscal responsibility might be sensibly defined as maintaining a zero value of the cyclicallyadjusted primary deficit.

19 The HP filter is applied to measures of provincial real GDP. Multiplying these measures by the GDP implicit price deflator yields an estimate of $Y^{*}$ measured in nominal dollars. Data on provincial real and nominal GDP is from CANSIM Table 3840038. These data are calendar year measures that span the period 1981-2012, inclusive. Since the data on provincial finances are measured on a fiscal year basis (April 1st to March 31st) fiscal year version of $Y$ and $Y^{*}$ is calculated using the formula $F Y_{t}=0.25 C Y_{t}+0.75 C Y_{t-1}$. 
application involves a minimum of judgment and requires a minimum of data. What's more, the resulting smooth but non-linear time series of potential output accords with most analysts' expectations of the evolution of that series. ${ }^{20,21,22}$

To arrive at estimates of the cyclically-adjusted primary deficit, $P D E F^{*}$, we employ an approach utilized by the IMF, the OECD and other research organizations. ${ }^{23}$ Cyclically sensitive components of the provincial budget are adjusted proportionately to the ratio of potential output to observed output, as determined by its elasticity with respect to the output gap. Thus,

$$
\begin{aligned}
T_{i, t}^{*} & =T_{i, t}\left(Y_{t}^{*} / Y_{t}\right)^{\alpha_{i}} & & \alpha_{i}>0 \\
S_{j, t}^{*} & =S_{j, t}\left(Y_{t}^{*} / Y_{t}\right)^{\beta_{j}} & & \beta_{j}>0
\end{aligned}
$$

where $T_{i, t}=$ observed revenue from revenue type $i$ in year $t, S_{j, t}=$ observed expenditure on program $j$ in year $t$, starred variables are values that would be observed at potential output, and $\alpha_{i}, \beta_{j}$ are elasticities measuring the sensitivity to output of revenue category $i$ and program expenditure $j$, respectively. Once values of $T_{i, t}^{*}$ and $S_{j, t}^{*}$ are calculated, the remaining (nonadjusted) categories are added in order to derive structural total revenues and expenditures.

20 A problem with using the HP filter is the so-called end-point problem; the fact the approach causes estimates of potential output at the beginning and at the end of the time series to be close to observed values of output. To deal with this issue, we follow a frequently used approach that involves extending the data series on output beyond the end, and prior to the beginning, of the study's sample period. Marianne Baxter and Robert King ("Measuring Business Cycles: Approximate Band-Pass Filters for Economic Time Series," Review of Economics and Statistics, Vol. 81, 1999) recommend adding at least three years of data (when using annual data) to each end of the sample period. Three years of data on provincial nominal output prior to 1981 (for years 1978-1980, inclusive) is taken from CANSIM series v123698 (Quebec) and v123985 (Ontario). In lieu of an implicit price deflator we rely on provincial measures of the consumer price index from CANSIM series D45062 (Quebec) and D45083 (Ontario) for those years. Forecasts of real and nominal provincial output for three years beyond the end of our sample (2013-2015) are taken from TD Economics, Provincial Economic Forecast, January 15, 2014.

21 An alternative approach to using the HP filter is to estimate an aggregate production function relating output to the inputs producing that output. The modelling requirements of this approach are significant as are the data requirements with the latter issue particularly acute at the sub-national level. Using Canadian provincial data, Yvan Guillemette ("A Simulation Model of Federal, Provincial, and Territorial Government Accounts for the Analysis of Fiscal-Consolidation Strategies in Canada," OECD Economics Department Working Paper No. 800, August 2010) shows that the production function approach yields similar estimates of provincial potential output to those produced by the HP filter.

22 A way of evaluating the "reasonableness" of estimates of potential output is to observe the value of the provincial unemployment rate in those years when our estimate of $Y^{*}$ is equal to observed output, $Y$. The unemployment rate in those years should be consistent with one's estimate of the full-employment (or 'natural') level of the unemployment rate. The values of potential output in Ontario and Quebec suggest that both of these provinces were at or near full employment in 1999 and again in 2008. In those years, the unemployment rate was 6.3 per cent and 6.6 per cent in Ontario and 9.3 per cent and 7.3 per cent in Quebec. As such, both the level and the change over time (falling in Quebec and slowly rising in Ontario) in these values accord with the views of most economists regarding the natural rate of unemployment in those provinces and in Canada.

23 See, for example, Fabian Bornhorst, Gabriela Dobrescu, Annalisa Fedelino, Jan Gottschalk and Taisuke Nakata, "When and How to Adjust Beyond the Business Cycle: A Guide to Structural Balances," IMF Fiscal Affairs Department, Technical Notes and Manuals, April 2011; Nathalie Girouard and Christophe Andre, "Measuring Cyclically-adjusted Budget Balances for OECD Countries," OECD Economics Department Working Paper No. 434, 2005; and Martin Larch and Alessandro Turrini, "The Cyclically-adjusted Budget Balance in EU Fiscal Policy Making: A Love at First Sight Turned into a Mature Relationship,” Economic Papers 374, European Commission, March 2009. 
The elasticity values used here, and the budget categories to which they are applied, are those suggested for application to Canadian data by the IMF. Specifically, the IMF suggests an elasticity value of 0.7 for personal income tax revenue, 1.5 for corporate income tax revenue, 1.0 of indirect tax revenue, 1.0 for other tax revenue, and -0.1 for program expenditures. ${ }^{24}$

Applying data to equation (2) also requires a value of the interest rate, $r_{t}$, observed in each year for each government. For this purpose an effective rate of interest paid by these governments is calculated as the amount paid in debt charges in year $t$ divided by the amount of net debt inherited from year $t-1$.

\section{WHO, OR WHAT, IS TO BLAME FOR DEBT ACCUMULATION?}

In this section, data describing the operating accounts of Ontario and Quebec are applied to the accounting framework described by equation (2). It is shown how this framework can be used to determine to what extent the fiscal policy choices of these two governments can be held responsible for the accumulation of debt.

\section{Ontario}

Figure 1 shows the annual change in the ratio of accumulated deficits to GDP (the debt ratio) due to the influence of the business cycle (the cyclical component) and due to policy choices (the policy component). It also identifies the political affiliation of the government in power.

Each of the coloured bars identifies the increase in the debt ratio, measured in percentage points of GDP, due to elements identified in equation (2). Bars above the zero line indicate the influence is such to cause the debt ratio to increase; bars below the line indicate the influence is in the direction of reducing the debt ratio. The blue line identifies the vertical sum of the bars for any year, and so, measures the total observed change in the debt ratio for that year. For example, in Ontario in 1986-87, one bar defines an influence pushing the debt ratio upward while the other defines an influence pulling the debt ratio downward. The bars are of nearly equal size indicating that, as shown by the blue line, there was no overall change in the debt ratio in that year. Over the entire period from 1982-83 to 2011-12, the ratio of accumulated deficits to GDP increased by 13.1 percentage points of GDP.

\footnotetext{
24 As reported in Bornhorst, et. al. "How and When to Adjust Beyond the Business Cycle," results are not terribly sensitive to alternative choices of these elasticity values. The values used are those suggested for Canada in the template accompanying that paper (http://www.imf.org/external/np/fad/strfiscbal/index.htm). Guillemette, "A Simulation Model," provides estimates for budget elasticities that are province-specific. With one exception, the elasticities he identifies for Ontario and Quebec do not differ significantly from what the IMF suggests for Canada (and which we use). The exception is the elasticity of personal income tax revenue which Guillemette determines to be only 0.4 in Quebec.
} 
FIGURE 1: ONTARIO

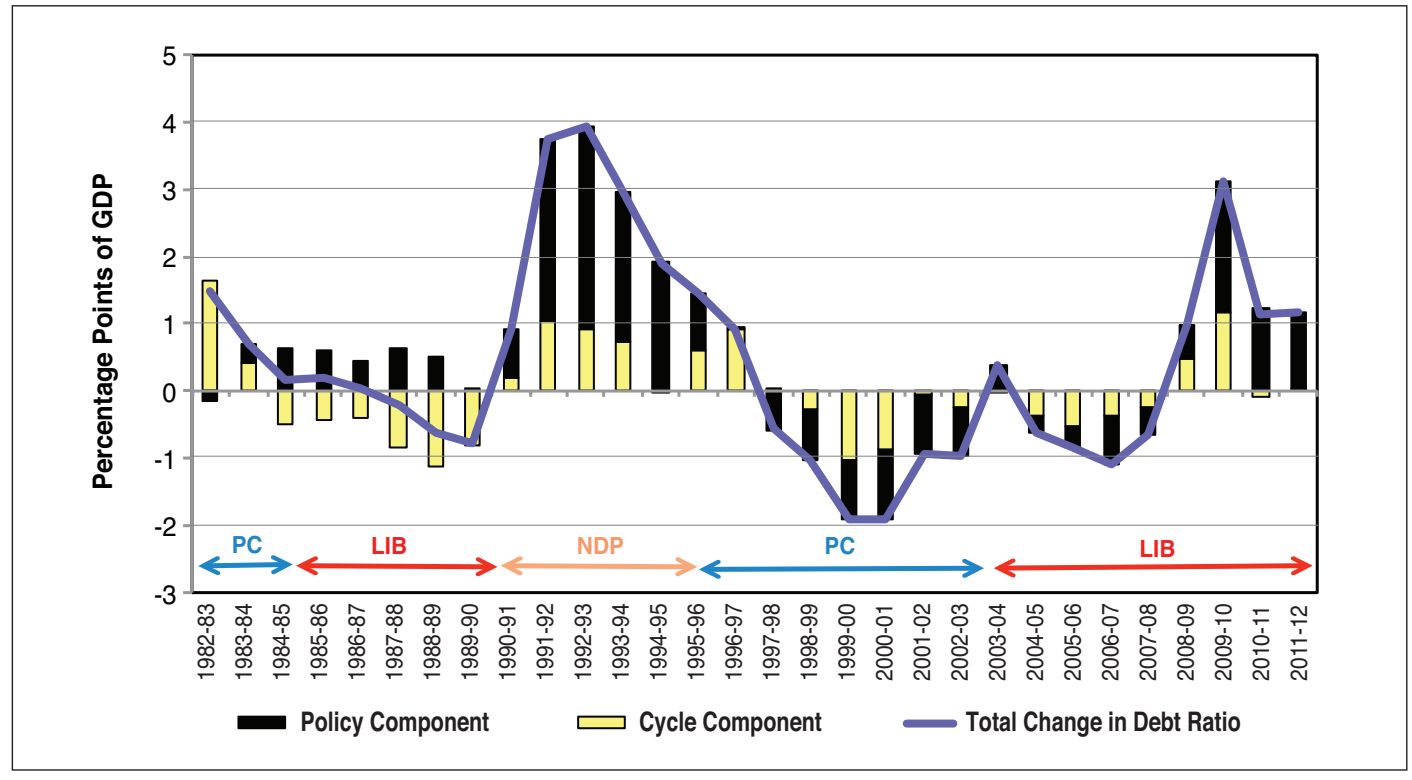

The yellow bars identify the cyclical component. Not surprisingly, the cyclical component was responsible for the debt ratio increasing during periods of recession in the early 1980s, the early 1990s and beginning in 2008. Periods of strong economic growth - the mid 1980s and from the mid 1990s to mid-2000s - saw the debt ratio fall as cyclically-sensitive revenues increased and cyclically-sensitive expenditures fell. Over the entire period from 1982-83 to 2011-12, the business cycle was responsible for none of the increase in Ontario's debt ratio; policy choices were wholly responsible for the increase in the debt ratio over this period.

The cyclical component is influenced by two considerations; by the deviation of output, $Y$, from potential output, $Y^{*}$ (which causes the observed primary deficit, $P D E F$, to deviate from its value at potential output, $P D E F^{*}$ ) and by the deviation of the observed growth rate of output, $n$, from the growth rate of potential output, $n^{*}$. Calculating that portion of the cyclical component due only to $n$ being different from $n^{*}$ provides an estimate of what would have happened to the debt ratio had governments continually adjusted tax rates and continually adjusted spending programs to always keep $P D E F=P D E F^{*}$. In other words, one would be showing the result of governments intentionally short-circuiting automatic stabilizers. This exercise shows that in Ontario, had governments behaved in this fashion over the entire period of our sample, they would have only reduced the debt ratio by 1.45 percentage points. The implication is that automatic stabilizers, over the 32 years of our sample, had a minimal impact on the accumulated deficit.

The black bars identify the change in the debt ratio due to the policy component. The policy component shows the effect on the debt ratio of discretionary changes in revenues and spending. A positive value for the policy component indicates that, given the economic environment as defined by the difference in the interest rate and the rate of growth in potential output, provincial fiscal policy choices will result in the accumulation of debt even when at full employment levels and growth rates of output. We argue that such a value for the policy component reflects a failure of government to respond to trends in its economic environment in a way that guarantees fiscal sustainability over the long-term. 
Observing a positive (negative) value for the policy component in a year of economic contraction (expansion) might be interpreted as indicative of a discretionary counter-cyclical policy. If so, one might judge it to be a desirable policy intervention. ${ }^{25}$ However, this interpretation requires accepting that discretionary provincial fiscal policies - particularly those stemming from changes in the government's operating account - have a favourable influence on output and/or the Bank of Canada's interest rate policies. If a provincial government recognizes, as we believe it should, that its fiscal policies can have no significant effect on output or market interest rates, then the effects of a positive policy component is negligible in the short term and, to the extent it results in an increase in the risk premium on its debt, negative in the long-term. A provincial government wishing to stimulate a contracting economy is generally advised to rely on its capital budget for this purpose; the idea being that investments in public infrastructure complementary to private production will have maximum stimulative and long-term benefits on the economy. This advice has the added benefit of steering governments away from using its operating account - where spending is dominated by health care, education and social services - to fund temporary expansions and contractions in their budgets.

\section{POLITICAL BOX SCORE: ONTARIO}

\begin{tabular}{|l|c|c|c|}
\hline Governing Party & Conservative & Liberal & $\begin{array}{c}\text { New } \\
\text { Democratic }\end{array}$ \\
\hline Years as government & 11 & 14 & 5 \\
Total debt accumulated as a result of policy choices (p.p. of GDP) & -3.2 & +5.7 & +10.6 \\
Average amount of debt accumulated as a result of policy & -0.3 & +0.4 & +2.1 \\
choices per year (p.p. of GDP) & & & \\
\hline
\end{tabular}

Another interpretation of the pattern exhibited by the black bars is one associated with politics. For this purpose, party affiliations of the government in power are identified in Figure 1. Summing the increases in the debt ratio caused by the policy choices of the government in power allows one to identify what some might suggest is the proclivity of certain political parties to add or subtract government debt. The results of this exercise, reported in the table above, confirms, for Ontario, the stereotype of governments on the right of the political spectrum maintaining more fiscally-conservative policies while those on the left choose to maintain a "looser" set of fiscal policies.

\section{Quebec}

Figure 2 presents the same information as Figure 1 but does so using data describing the finances of the government of Quebec. The same vertical scale on the two figures is used to enable an easier comparison of the results for the two provinces. Cyclical influences have been generally larger in Quebec, while the policy influences have generally been larger in Ontario. Over the entire period from 1982-83 to 2011-12, the debt ratio in Quebec increased by 8.4 percentage points of GDP.

${ }^{25}$ We thank Bev Dahlby for raising this point. 
FIGURE 2: QUEBEC

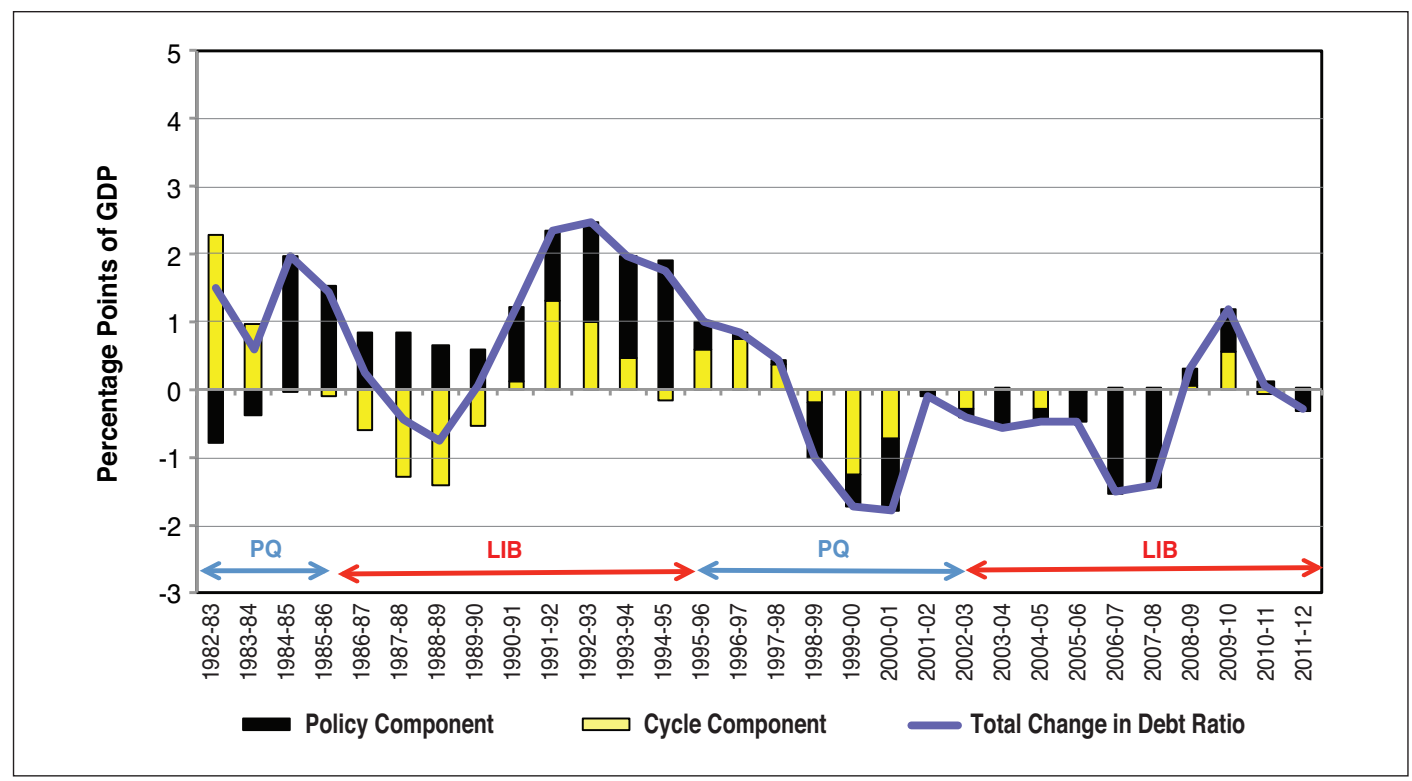

As in Ontario, in Quebec, the recessions of the early 1980s, early 1990s and the more recent recession starting in 2008 caused the debt ratio to increase. Over the entire period from 198283 to 2011-12, the business cycle was responsible for adding 1.6 percentage points of GDP to Quebec's debt ratio. ${ }^{26}$ The remaining debt accumulated by the operating account, equal to 6.8 percentage points of GDP, was due to the policy choices of the provincial government.

\section{POLITICAL BOX SCORE: QUEBEC}

\begin{tabular}{|c|c|c|c|}
\hline \multirow[t]{2}{*}{ Governing Party } & \multirow{2}{*}{$\begin{array}{c}\text { Parti } \\
\text { Québécois }\end{array}$} & \multicolumn{2}{|c|}{ Liberal } \\
\hline & & Bourassa & Charest \\
\hline Years as government & 12 & 9 & 9 \\
\hline Total debt accumulated as a result of policy choices (p.p. of GDP) & +0.3 & +9.9 & -3.5 \\
\hline $\begin{array}{l}\text { Average amount of debt accumulated as a result of policy choices } \\
\text { per year (p.p. of GDP) }\end{array}$ & +0.03 & +1.1 & -0.4 \\
\hline
\end{tabular}

As per Ontario, it is interesting to observe how the amount of debt accumulated as a consequence of policy choices is related to the government in power. Whereas the policy component in Ontario is consistent with the stereotype of governments on the right of the political spectrum maintaining more fiscally-conservative policies with those on the left choosing to maintain a "looser" set of fiscal policies, in Quebec, the evidence is less supportive of the usual right-left stereotype. During their 12 years on power, the Parti Québécois, an unabashedly left-wing party, added a total of just 0.3 percentage points of GDP to the debt ratio, and so, on average maintained a virtual balance on the current account. The Liberals exhibited more schizophrenic behaviour with the government of Robert Bourassa adding large amounts of debt - and doing so in every year of its mandate - while the government of Jean Charest did the opposite.

${ }^{26}$ Reporting only that portion of the cyclical component resulting from $n$ being different from $n *$ one determines what role automatic stabilizers played in debt accumulation. The calculation for Quebec is similar to that for Ontario; over the 32 years of the sample period automatic stabilizers increased the debt ratio by only 1.38 percentage points. 
Comparing the two provinces, one observes a broadly similar pattern whereby policy choices lead to a rapid accumulation of debt during the 1980s and early 1990s. The latter half of the 1990s and the 2000s were periods of policy-induced retrenchments. More recently, and particularly in Ontario, there has been a return to policy-induced debt accumulation.

\section{LOOKING AHEAD}

The purpose of defining an operating account is for governments to be clear that the expenditures in that account are such that they ought to balance, or balance as closely as possible, with revenues over the long term. Over a long enough period of time, one expects the accumulated deficits of the current account to sum to zero.

The government of Quebec would appear to appreciate the logic of reducing the accumulated deficit on its current account; it has stated a goal of halving the size of this debt, as a fraction of GDP, by $2025-26 .{ }^{27}$ No similar commitment can be found on the part of the government of Ontario beyond a vague statement in which it commits to reducing its debt ratio to prerecession levels sometime in the future..$^{28}$

Suppose one accepts that both provinces understand the need to reduce the accumulated deficits on their current accounts. What would be the budget implications?

\section{Ontario}

As a first step to understanding what Ontario needs to do in the future, it is useful to observe the size of the policy component in the last year of this sample (2011-12). In Ontario, the policy component in that year was equal to +1.1 per cent of GDP. This means that the setting of tax rates and the design of spending programs were such that the debt ratio would increase by 1.1 percentage points per year even assuming the economy of Ontario was operating at full employment. ${ }^{29}$

27 See Quebec Budget 2013-14. The commitment is to reduce the accumulated deficit on the current account to 17 per cent of GDP by 2025-26. Due to changes to government accounting that have been introduced over the 30 years of our sample, the size of the accumulated deficit on the current account at the end of fiscal year 2012 that is calculated by the government - 34 per cent of GDP - differs somewhat from ours (28.6 per cent). By our estimates, for Ontario to return to its pre-recession debt ratio, it would need to reduce it by 6.4 percentage points or by about one-quarter.

28 See Ontario Budget 2013-14.

29 As seen in Figure 1, 2011-12 was not an anomaly. From 2009-10 to 2011-12, the estimate of the value of PDEF* averaged $+\$ 3.7$ billion. This compares to an average value of $-\$ 6.4$ billion during the three years prior to 2009-10. The policy component during these years was equal to 1.9, 1.2 and 1.1 percentage points of GDP. 
As shown in equation (2) above, there are two possible reasons for this result. One is the difference between the interest rate paid on government debt, $r$, and the rate of growth in potential output, $n^{*}$. As discussed below, this difference normally causes the debt ratio to grow. That was, in fact, the case in 2011-12. The other reason is the size of the primary deficit at full employment, $P D E F^{*}$. The government of Ontario established tax rates and designed spending programs which, since 2009-10, yielded large positive values of $P D E F^{*}$. The government, then, was making fiscal policy choices that would cause both sources of change in the policy component - the difference in $r$ and $n^{*}$ and the size of $P D E F^{*}-$ to add to the debt ratio.

In 2011-12, Ontario was operating below potential as it continued its prolonged recovery from recession. However, the economy was expanding toward potential, and so, the rate of growth in GDP, $n$, exceeded the rate of growth in potential output, $n^{*}$. The net effect of being below potential output but growing closer to it - a net effect measured by the cyclical component was a very small addition to the debt ratio. The increase in the debt ratio in 2011-12, then, was almost wholly due to the fiscal policy choices of the Ontario government.

Looking ahead, the government of Ontario faces a number of challenges related to its fiscal policy choices. Economic conditions are improving with the result that the change in the debt ratio due to cyclical component has all but disappeared. The challenge is now to reduce the size of the cyclically-adjusted primary deficit, $P D E F^{*}$. In particular, it needs to be adjusted from a positive to a negative value (i.e., from a cyclically-adjusted primary deficit to a cyclically-adjusted primary surplus). This is necessary simply to halt the growth in the debt ratio; to reduce the ratio requires still stronger measures.

One gains an understanding of the choices to be faced by the government of Ontario by using equation (2) to forecast what future budgets might need to deal with. For this exercise, it is assumed that in 2012-13, the economy of Ontario settles to and remains at a level of GDP equal to its potential level (i.e., assuming $Y=Y^{*}$ and $n=n^{*}$ ). The implication of this assumption is that the primary deficit adjusts to its cyclically-adjusted value (i.e., $P D E F=$ $\left.P D E F^{*}\right)$. Finally, it is assumed that the interest rate paid on Ontario government debt remains constant at 3.5 percentage points above the rate of potential GDP growth (i.e., $\left(r-n^{*}\right)=$ $0.035){ }^{30}$

With these assumptions, and assuming the size of the cyclically-adjusted primary deficit as a fraction of GDP remains constant at its 2011-12 value, the ratio of accumulated deficits to GDP (the debt ratio) rises steadily from 23.4 per cent to 41.5 per cent of GDP by 2025-26.

Clearly, Ontario has some hard decisions to make in order to hit its target of returning the debt ratio to pre-recession levels (about 18 per cent), never mind any longer-term goal to reduce this debt altogether.

30 The choice of this value reflects three considerations. First, Canada is generally recognized as a dynamically-efficient economy. The implication is that it will usually be the case that the rate of interest will exceed the rate of economic growth. Second, values for Ontario and Quebec averaged about four per cent during the last few years of the period of analysis and were slowly falling. Finally, evidence from the IMF (Julio Escolano, "A Practical Guide to Public Debt Dynamics, Fiscal Sustainability, and Cyclical Adjustment of Budgetary Aggregates," IMF Technical Notes and Manuals, January 2010) suggests a similar value (3.8 per cent) for Canada using data that excludes the recent period of lower interest rates. The assumed value of 3.5 per cent should, therefore, be understood to be conservative in the sense of requiring smaller adjustments in taxation and spending to meet the targets defined in this section than would otherwise be the case. 
What are some possibilities? Nothing can be done to reduce the debt ratio that does not involve turning what is now a cyclically-adjusted primary deficit into a surplus. This requires, at minimum, a $\$ 1.7$ billion increase in taxes, cut to spending, or some combination of those options. But that will not be nearly enough; this will only slow the rate of increase in the debt ratio. By 2025-26, a fiscal response of this size, even if implemented immediately, will only cause the debt ratio to hit 37 per cent, rather than 41.5 per cent, of GDP. Something more drastic is required. An immediate and permanent increase in taxes, cuts to spending or some combination of these options of $\$ 7$ billion would, assuming that thereafter the primary balance grows at the rate of potential GDP, hold the debt ratio constant at its current value. To actually reduce the debt ratio from its current value would require a still larger adjustment. For example, an immediate and permanent increase in taxes (or cut to spending) of $\$ 9.3$ billion would put the debt ratio on a downward trajectory toward a value of 18 per cent of GDP by 2025-26.

How big is a $\$ 9.3$ billion adjustment to the primary deficit? Were the adjustment made solely via a spending cut, it would require an eight per cent cut to the level of total program spending observed in 2011-12. This cut, spread across spending on health, education and social services in proportion to the fraction of program spending going to those categories, would require a $\$ 3.8$ billion cut to health spending, a $\$ 2.5$ billion cut to education spending, and an $\$ 1$ billion cut to spending on social services with the remaining $\$ 1.8$ billion coming from other spending cuts. If instead, the adjustment was made with revenue increases, it would require, for example, a 3.5 percentage point increase in the HST (from 13 per cent to 16.5 per cent), a doubling of the corporation income tax, or a 40 per cent increase in the personal income tax (all using 2011-12 values). Of course, some combination of spending cuts and tax increases would also work.

A $\$ 9.3$ billion adjustment to the primary deficit would mean turning the 2011-12 cyclicallyadjusted deficit of $\$ 1.7$ billion into a surplus of $\$ 7.6$ billion. This would not be an extraordinary value for the cyclically-adjusted primary balance. In fact, by these calculations, Ontario had a cyclically-adjusted primary surplus equal to $\$ 7.6$ billion as recently as 2007-08. It would mean, then, undoing some fairly recent policy changes. Between 2007-08 and 201112 , it is estimated that program spending, (adjusted for the business cycle), increased by $\$ 17$ billion (19 per cent) while revenues increased by $\$ 8.5$ billion (or eight per cent). ${ }^{31}$ What is necessary, then, is to reverse the recent tendency to increase spending without the extra tax revenue to fund that spending. It means a return to what was a policy in place only a few years ago; a policy of maintaining a cyclically-adjusted primary surplus of between $\$ 7$ and $\$ 8$ billion. This can be done either by increasing tax rates so as to allow revenue to catch up to spending, by reversing recent increases in spending commitments, or some combination of these choices.

31 About half of that increase in spending was on Health and about one-third was on Education. Spending on all of the "Big Three" of provincial spending responsibilities - Health, Education and Social Services - increased at rates well in excess of the increase in cyclically-adjusted tax revenue. The fastest growing of the three categories was Health. 
An immediate $\$ 9.3$ billion adjustment in Ontario's primary balance in not necessary. A more gradual adjustment - for example, raising taxes or cutting spending by $\$ 3.4$ billion per year in each of the next three years - would have the same success at reducing the debt ratio to 18 per cent of GDP though, as this example illustrates, slowing the pace of adjustment increases the size of the total adjustment required. Many options are available but they must all involve turning what is currently a cyclically-adjusted primary deficit into a surplus and this requires much more than simply slowing the rate of growth in the size of the primary balance.

While on the one hand, one might suggest a gradual adjustment to cyclically-adjusted primary balance, on the other, one might suggest a rather more ambitious target for the debt ratio than simply returning it to its pre-recession level. After all, the idea of identifying an operating account in government budgeting is to more easily identify the bills that need to be paid by current as opposed to future tax payers. The aim, then, would be to target a zero value for the accumulated debt.

Wary of trying to peer too far into the future or asking for too rapid an adjustment, another exercise considered here is to ask only what policy choices are necessary to establish a debt ratio of 10 per cent by 2025-26. Assuming the extra adjustment takes place early, an additional year of $\$ 3.4$ billion spending cuts or tax increases - in addition to the three straight years of cuts required to reduce the ratio to pre-recession levels - would do the trick.

\section{Quebec}

In Quebec, the policy component in 2011-12 was equal to -0.3 per cent of GDP. This means that the setting of tax rates and the design of spending programs were such that the debt ratio would decrease by 0.3 percentage points per year assuming the economy of Quebec is at full employment.

In 2011-12, Quebec was operating slightly below potential as it too continued its prolonged recovery from recession. Like Ontario, the economy was expanding toward potential, and so, the rate of growth in GDP exceeded the rate of growth in potential output. The net effect of being below potential output but growing closer to it - a net effect measured by the cyclical component - was to pull the debt ratio slightly upward (see Figure 2). The decrease in the debt ratio in 2011-12, then, was wholly due to the fiscal policy choices of the Quebec government.

As noted above, the change in the debt ratio due to government policy reflects the combined influences of the difference in the interest rate paid on Quebec government debt $(r)$ and the rate of growth in potential output $\left(n^{*}\right)$, and the size of the cyclically-adjusted primary deficit, $P D E F^{*}$. The first influence, due to the difference in $r$ and $n^{*}$, is to push the debt ratio upward. The fact that Quebec's policy component was dragging the debt ratio lower in 2011-12 is, then, solely due to the government having set tax rates and designing spending programs in a way to yield a negative value of the cyclically-adjusted primary deficit. In other words, the falling debt ratio is due to the government of Quebec making fiscal policy choices that yield a sizable cyclically-adjusted primary surplus. We estimate the size of cyclically-adjusted primary surplus to have been $\$ 4.3$ billion in 2011-12. 
Looking ahead, the government of Quebec has more favourable policy options to choose from than has the government of Ontario. Quebec's fiscal policy choices are already causing the debt ratio to fall; the only question is whether the current rate of decrease is sufficient to hit the government's $2025-26$ target for the debt ratio. ${ }^{32}$

Just as was done with Ontario, one can gain an understanding of the choices to be faced by the government of Quebec by using equation (2) to forecast what future budgets might need to deal with. To do this, it was again assumed that in 2012-13 the economy of Quebec settled to and remains at a level of GDP equal to its potential level and that as a result the cyclical component is set to zero. As with Ontario, it is assumed that the interest rate paid on Quebec government debt remains constant at 3.5 percentage points above the rate of potential GDP growth (i.e., $\left(r-n^{*}\right)=0.035$ ).

With these assumptions, and assuming the size of the cyclically-adjusted primary deficit remains constant at its 2011-12 values as a fraction of GDP, the debt ratio falls, but only slightly, from 28.6 per cent to 24.8 per cent of GDP by 2025-26. This leaves the debt ratio above the level the government of Quebec has identified as its target level to be reached in 2025-26 (18 per cent). Quebec, then, also needs to make an adjustment to the size of its primary balance. An advantage Quebec has over Ontario is that because the balance is already in surplus, a relatively small adjustment is required. For example, an immediate one-time cut to spending or increase in revenue (or some combination) that increases the size of the primary surplus by $\$ 1.4$ billion would be enough to lower the debt ratio to 18 per cent by $2025-26$. A cut of $\$ 1.4$ billion is equal to just over two per cent of program spending (using 2011-12 values), and so, is considerably less than the adjustments required in Ontario. Smaller annual adjustments spread over a number years could yield the same result. ${ }^{33}$

Finally, as was done with Ontario, it is possible to ask what it would take for the government of Quebec to hit a more ambitious target for its debt ratio. It turns out that a second year of spending cuts or tax increases equal to $\$ 1.4$ billion - would be sufficient to reduce the debt ratio to 10 per cent by $2025-26$.

\section{CONCLUSION}

As recently emphasized by Busby and Robson, ${ }^{34}$ nothing is simple when it comes to working with government financial data. Yet, an understanding of what drives the accumulation of government debt requires a time series describing government finances that is internally consistent insofar as the effect of spending and revenue choices on debt can be clearly identified. One of the contributions of this report is to provide such information for the governments of Ontario and Quebec.

\footnotetext{
32 The significance of having established a negative value for the primary deficit is apparent when one recognizes that were the government of Quebec willing to simply hold the ratio of accumulated deficit to GDP constant, it could increase spending and/or cut taxes by about $\$ 100$ million in every year to 2025-26.

33 In Quebec, spending on Health was been responsible for 55 per cent of the increase in program spending between 2007-08 and 2011-12. As was the case in Ontario, the increase in spending on all of the Big Three of provincial spending responsibilities increased faster than cyclically-adjusted revenue. The fastest growing of the three categories was, as in Ontario, Health.

34 "Credibility and the Bottom Line."
} 
The second contribution of this paper is to define an accounting framework that allows one to identify how much government debt has been accumulated as a consequence of policy choices as opposed to the effects of the business cycle. This framework shows that using the size of the cyclically-adjusted primary deficit $\left(P D E F^{*}\right)$ for this purpose is wrong. It is wrong because it assumes that governments are not responsible for paying the interest on the debts they have inherited from previous governments. It is also wrong because this metric fails to recognize that changes in the economic environment demand a response in the form of adjustments to tax rates and/or changes in the design of programs. This paper's accounting framework corrects these shortcomings.

The final contribution made by this paper is to show how this framework can be used to look backwards to evaluate the extent to which policy choices have contributed to changes in the debt ratio, and forward to offer commentary on what future policy choices need to be made to hit certain targets for the debt ratio. These calculations show that, while over certain periods, the business cycle has played a role in debt accumulation, over the 30 years described by our data, the effects of economic booms and busts have been offsetting in their influence on government debt in Ontario and Quebec. Virtually all of the debt incurred by these governments has therefore been the result of policy choices. Looking ahead, both governments need to impose increases in tax rates and/or lower levels of public services in order to reduce their debt levels. The burden of these adjustments will be considerably heavier for the citizens of Ontario to carry than those required of the citizens of Quebec.

As a final comment, it is important to note that this paper has only examined the changes in the accumulated deficits of the operating accounts of these two provinces. Thus, the focus has been on the accumulation of \$224 billion of debt in Ontario and \$153 billion in Quebec over the period 1980/81 to 2011/12. As noted earlier, this paper has not discussed the accumulation of over $\$ 81$ billion in Ontario and $\$ 67$ billion in Quebec that is the result of government borrowing to finance extraordinary expenditures on bailouts, privatizations and purchases of infrastructure. If one were to assume, perhaps heroically, that all of that latter borrowing was the result of policy decisions that accurately balanced the benefits of such spending accruing to future tax payers to the taxes they will pay, then the benefits and costs of that debt have been balanced and that debt is not a serious concern. The same, however, cannot be said of debt incurred on a government's operating account where taxation is meant to balance the costs of providing goods and services to current taxpayers. That debt, then, is a whole different kettle of fish. 


\section{APPENDIX}

The following two tables present the provincial budget data used in this study. These data comes from the Public Accounts of the two provinces and are measured in millions of nominal dollars.

These data relate to the General Fund (Quebec) and the Operations Account (Ontario) only. As explained in the text, the Accumulated Deficit is the sum of the Annual Deficits in these accounts. The Accumulated Deficit differs from the Net Debt as the latter includes the accumulated deficits from government funds other than the General Fund and the Operating Fund.

Similar data are contained in the Fiscal Reference Tables (FRT) published by the federal Department of Finance. However, the data in the following tables goes beyond what is found in the FRT by reporting not only total spending and total revenue but also revenues and expenditures by categories. This breakdown of revenue and expenditures by sub-categories is necessary to cyclically-adjust the deficit and, so, the accumulated deficit.

The FRT adds a column, "Other", that represents the net balance (revenue - expenditure) of all government funds other than the General Fund and the Operations Account. The deficit reported in the FRT is not, therefore, the deficit of the General Fund and Operating Fund but is, rather, the deficit of the provincial consolidated budget.

Accounting reforms in 1997-98 caused the Government of Quebec to re-state amounts previously reported in its public accounts. This paper reports the values as originally reported rather than try to unravel the implications of these accounting changes. The difference in this data versus the data reported in the FRT for Quebec is minor.

A difference between the data for Ontario and those data presented in the FRT is for years 1993-94 to 2000-01. For those years, FRT data in the category 'Own Source Revenues' are higher and Total Program Expenditures are lower - by the same amounts - than is reported in the following table. For those years the FRT allocated an amount from Total Program Expenditures to Own Source Revenues to reflect a change in the government's treatment of education property tax revenues. The FRT attempts to make this adjustment only for the years 1993-94 to 2000-01. In constructing the data set provided below, no attempt was made to make this adjustment. Instead, it reports revenues and expenditures as reported in the Public Accounts when published. It is noteworthy that the adjustments reported in the FRT have no impact on the size of the Ontario deficit/surplus. The deficit/surplus reported in the FRT (which is the same as we report) does not equal the change in Net Debt reported in the FRT. The Net Debt figure in the FRT therefore includes the debt implications of extraordinary expenditures such as the impact of electricity market restructuring. 


\section{Quebec}

\begin{tabular}{|c|c|c|c|c|c|c|c|c|c|c|c|c|c|c|c|c|}
\hline \multirow[b]{2}{*}{ 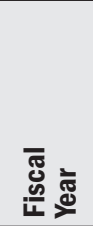 } & \multicolumn{6}{|c|}{ Revenue } & \multicolumn{7}{|c|}{ Expenditure } & \multirow[b]{2}{*}{ 焉考 } & \multirow[b]{2}{*}{ 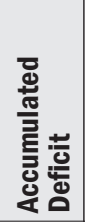 } & \multirow[b]{2}{*}{ 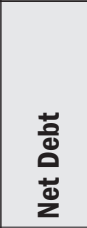 } \\
\hline & 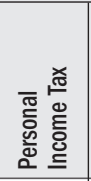 & 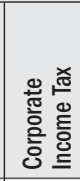 & 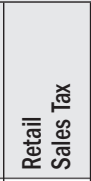 & 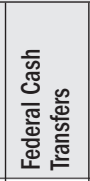 & 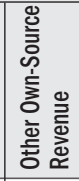 & 焉 & $\begin{array}{l}\text { 䔍 } \\
\text { 堊 }\end{array}$ & 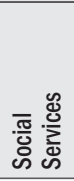 & 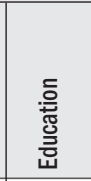 & 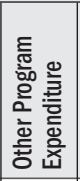 & 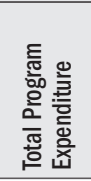 & 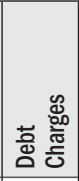 & 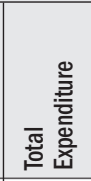 & & & \\
\hline $1980-81$ & 5,374 & 1,515 & 1,962 & 3,894 & 1,727 & 14,472 & 5,070 & 1,530 & 5,499 & 472 & 16,571 & 1,382 & 17,953 &, 481 & 14,326 & 4,326 \\
\hline 19 & 119 & 2,285 & 2,087 & 4,473 & 2,778 & 17,742 & 5,826 & 704 & 6,016 & 4,867 & 18,413 & 1,950 & 20,363 & 621 & 947 & 12,569 \\
\hline $1982-8$ & 526 & 2,235 & 2,275 & 5,172 & 3,349 & 19,557 & 6,174 & 2,124 & 6,270 & 5,152 & 19,720 & 2,300 & 22,020 & ,463 &, 410 & 15,038 \\
\hline 19 & 959 & 2,001 & 2,655 & 6,227 & 3,799 & 21,641 & 6,600 &, 475 & 6,510 & 5,709 & 21,294 & 2,511 & 23,805 & 164 & 1,574 & 17,298 \\
\hline $1984-8$ & 34 &, 506 & 2,991 & 6,236 & 2,984 & 22,065 & 7,175 & 652 & 6,876 & 6,223 & 22,926 & 3,012 & 25,938 & 873 & 5,447 & 21,455 \\
\hline $1985-86$ & 8,150 & 2,683 & 3,630 & 6,178 & 3,332 & 23,973 & 7,677 & 678 & 7,464 & 6,273 & 24,092 & 3,354 & 27,446 & ,473 & 8,920 & 25,735 \\
\hline $1986-87$ & 8,657 & 46 & 4,124 & 5,828 & 3,698 & 25,353 & 8,175 & 760 & 7,749 & 6,085 & 24,769 & 3,556 & 28,325 & 972 & ,892 & 28,716 \\
\hline $1987-$ & 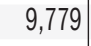 & 1 & 4,568 & 6,117 & 4,124 & 28,109 & 8,857 & 906 & 8,692 & 375 & 26,830 & 3,675 & 05 & 396 & 88 & 31,115 \\
\hline $8-8$ & 0.377 & 40 & 4,870 & 6,386 & 4,379 & 29,752 & 9,576 & 787 & 8,684 & 607 & 27,654 & 3,802 & 31,456 & 704 & 5,992 & 32,819 \\
\hline 9.8 & 777 & 99 & 113 & 6,674 & 4,110 & 31,033 & 10,299 & ,930 & 8,468 & 085 & 28,782 & 4,015 & 32,797 & 764 &, 756 & 83 \\
\hline 1990-91 & 1 & 3 & 5,353 & 6,972 & 4,156 & 33,045 & 312 & ,018 & 9,430 & 7,823 & 31,583 & 4,437 & 36,020 & ,975 & 0,731 & 37,55 \\
\hline 1991-92 & 502 & 1 & 6,158 & 6,747 & 4,439 & 34,467 & 12,341 & 3,623 & 9,969 & 169 & 34,102 & 4,666 & 38,768 & 301 & ,032 & $\Delta 1$ \\
\hline $1992-93$ & 10 & 4 & 6,000 & 7,764 & 4,795 & 35,325 & 697 & 4,061 & 10,360 & 481 & 35,599 & 4,756 & 40,355 & 030 & 62 & $\Delta 6$ \\
\hline 3-94 & ,313 & 4,885 & 5,583 & 7,762 & 5,384 & 35,927 & 13,010 & 4,725 & 10,231 & 7,568 & 35,534 & 5,316 & 40,850 & 4,923 & 1,985 & 51, \\
\hline 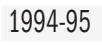 & 12,453 & 3 & 5,430 & 7,494 & 5,509 & 36,309 & 13,137 & 4,874 & 10,521 & 7,716 & 36,248 & 5,882 & 42,130 & 821 & 0,806 & 57 \\
\hline $1995-96$ & 988 & 6,211 & 5,614 & 8,126 & 5,187 & 38,126 & 13,101 & 5,006 & 10,453 & 7,479 & 36,039 & 6,034 & 42,073 & 47 & 53 & 61 \\
\hline $1996-97$ & 220 & 9 & 5,213 & 6,704 & 5,390 & 37,226 & 12,920 & 4,943 & 10,040 & 6,680 & 34,583 & 5,855 & 38 & 12 & 65 & \\
\hline 1.9 &, 531 & 6 & 5,488 & 5,656 & 3,060 & 36,071 & 12,923 & 5,057 & 9,449 & 5,553 & 32,982 & 7,039 & 40,021 & 50 & & \\
\hline 1998-99 &, 400 & 3 & 6,426 & 7,813 & 3,587 & 40,749 & 14,596 & 5,672 & 9,580 & 534 & 35,382 & 6,853 & 42,235 & 36 & 01 & \\
\hline-0 & 074 & 34 & 6,761 & 6,064 & 4,648 & 41,481 & 831 & 5,598 & 9,825 & 748 & 36,002 & 7,035 & 7 & 56 & 57 & \\
\hline 0-01 & 984 & 8,705 & 7,374 & 7,895 & 4,384 & 45,342 & 16,095 & 5,530 & 10,124 & 6,568 & 38,317 & 7,248 & 65 & 23 & 80 & 88 \\
\hline $2001-0$ &, 274 & 8,320 & 7,294 & 8,885 & 4,750 & 44,523 & 17,186 & 5,167 & 10,615 & 7,106 & 40,074 & 6,930 & 44 & 31 & & 12 \\
\hline 2( &, 597 & 3 & 8,051 & 8,932 & 5,850 & 46,233 & 17,872 & 5,457 & 11,166 & 7,339 & 41,834 & 6,804 & 38 & 405 & 66 & 95 \\
\hline 20 &, 715 & 11 & 8,658 & 9,370 & 5,905 & 48,189 & 19,063 & 5,655 & 11,568 & 7,041 & 43,327 & 6,850 & 77 & 988 & 54 & 25 \\
\hline 20 & 16,324 & 9,127 & 9,241 & 9,229 & 6,377 & 50,298 & 20,622 & 5,624 & 11,874 & 7,332 & 45,452 & 7,035 & 52,487 & 189 & 43 & 99 \\
\hline 2 & 44 & 3 & 14 & 9,969 & 6,478 & 52,343 & 21,163 & 5,677 & 12,280 & 7,645 & 46,765 & 7,042 & 07 & 464 & & 1 \\
\hline 20 & 48 & 2 &, 873 & 015 & 7,999 & 57,199 & 22,453 & 5,853 & 12,638 & 8,078 & 49,022 & 7,185 & 56,207 & -992 & 15 & 12 \\
\hline 20 & 1 & 3 &, 011 & 13,629 & 7,990 & 59, & 24,054 & 5,944 & 13,399 & 77 & 51,774 & 7,160 & 34 & 576 & 39 & 12 \\
\hline 20 & 1 & 7 &, 472 & 023 & 8,030 & 5 & 25,621 & 6 , & 14 & 18 & 55,197 & 6,639 & 36 & 2,661 & 300 & 13 \\
\hline $2009-10$ & 16,459 & 9,398 & 0,473 & 15,161 & 7,799 & 59,290 & 27,466 & 6,372 & 14,653 & 24 & 58,215 & 6,240 & 55 & 5,165 &, 965 & 151,608 \\
\hline 201 & 17,913 & 9,613 & 1 & 15,425 & 8,231 & 62,650 & 28,514 & 6,553 & 15 & 16 & 59,978 & 7,084 & 67, & 4,412 & 377 & 159,333 \\
\hline $2011-12$ & 980 & 1 & 13,159 & 15,243 & 7,993 & 65,515 & 29,341 & 6,783 & 15,634 & 9,745 & 61,503 & 7,348 & 68,851 & 3,336 & 99,713 & 16 \\
\hline
\end{tabular}




\section{Ontario}

\begin{tabular}{|c|c|c|c|c|c|c|c|c|c|c|c|c|c|c|c|c|}
\hline \multirow[b]{2}{*}{ 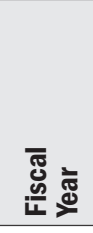 } & \multicolumn{6}{|c|}{ Revenue } & \multicolumn{7}{|c|}{ Expenditure } & \multirow[b]{2}{*}{ 焉志 } & \multirow[b]{2}{*}{ 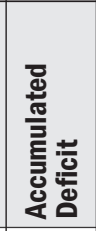 } & \multirow[b]{2}{*}{ 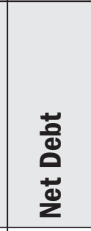 } \\
\hline & 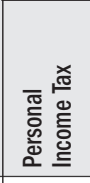 & 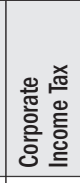 & 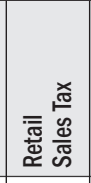 & 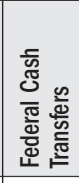 & 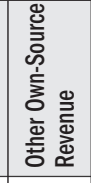 & 焉离 & $\begin{array}{l}\text { 焉 } \\
\text { Ф़ }\end{array}$ & 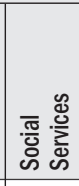 & 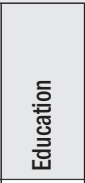 & 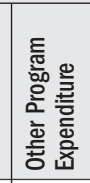 & 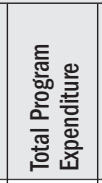 & 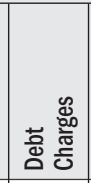 & 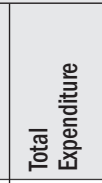 & & & \\
\hline $1980-8$ & 3,578 & 792 & 2,562 & 25 & 4,088 & 15,045 & 4,867 & 516 & 3,790 & 4 & 287 & 055 & 6,342 & 1,297 & 11,988 & 11,9 \\
\hline 100 & 4,928 & 769 & 2,853 & 3,308 & 4,433 & 17,291 & 5,784 & 761 & 4,353 & 64 & 7,862 & 1,209 & 19,071 & 1,780 & 13,768 & 13,7 \\
\hline 1982 & 5,858 & 361 & 3,420 & 3,345 & 4,835 & 18,819 & 6,746 & 113 & 4,644 & 13 & 0,446 & \begin{tabular}{|l|} 
\\
\end{tabular} & 22,008 & 3,189 & 16,957 & 16,94 \\
\hline $1983-$ & 5,994 & 583 & 3,876 & 4,161 & 5,344 & 20,958 & 7,568 & ,390 & 5,058 & 15 & 2,031 & 2,080 & 24,111 & 3,153 & 20,110 & 20,182 \\
\hline 1984 & 6,253 & ,248 & 4,426 & 4,578 & 5,883 & 23,388 & 8,328 &, 592 & 5,310 & 00 & 3,530 & 2,417 & 25,947 & 2,559 & 22,669 & 22,848 \\
\hline 1985 & 7,249 &, 575 & 5,025 & 4,682 & 6,254 & 25,785 & 9,245 & 859 & 5,845 & 655 & 5,604 &, 795 & 28,399 & 2,614 & 25,283 & 28,919 \\
\hline $1986-$ & 8,618 & 3,205 & 5,604 & 4,870 & 6,919 & 29,216 & 10,480 & ,270 & 6,805 & 083 & ;638 & \begin{tabular}{|l|}
3 \\
3,211
\end{tabular} & 31,849 & 2,633 & 27,916 & 1,4 \\
\hline $1987-$ & 9,859 & 600 & 05 & 984 & 7,410 & 32,158 & 11,976 & 322 & 7 & 8 & 171 & 476 & 4,647 & 2,489 & 05 & 34,020 \\
\hline 19 & 687 & 223 & 775 & 113 & 8,193 & 3 & 13,043 & 41 & 7,7 & 66 & 703 & 767 & 470 & 1,479 & 84 & 35,499 \\
\hline 10 & 518 & 720 & 49 & 84 & 74 & 4 & 1 & 17 & 8,299 & 69 & 18 & 17 & 41,135 & -90 & 94 & \\
\hline $1990-91$ & 440 & 800 & 10 & 5,762 & 9,715 & 2 & 1 & 155 & 8,981 & 1 & 45 & 76 & 21 & 3,029 & & $38,43 \varepsilon$ \\
\hline 10 &, 712 & 104 & 7,487 & 6,324 & 10,046 & 40,753 & 17,582 & ,207 & 10,158 & 10,540 & 487 & 196 & 51,683 & 10,930 & 753 & \\
\hline 1 & 543 & 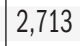 & 316 & 554 & 10,681 & 07 & 17,755 & 10,339 & 07 & 1 & 942 & 293 & 35 & 12,428 & 81 & 1. \\
\hline 1 & 723 & 年1 & 124 & 071 & 09 & 74 & 1 & 42 & 90 & 1 & 747 & 29 & 376 & 11,202 & 83 & 80,59 \\
\hline 1 &, 758 & vi & 90 & 607 & 27 & 9 & 1 & 36 & 21 & 1 & 36 & 832 & 68 & 10,129 & 512 & 90,728 \\
\hline 10 & 633 & . 114 & 9,424 & 380 & 1 & 473 & 17,775 & 30 & 61 & 1 & 98 & 475 & 73 & 8,800 & 12 & 2 \\
\hline 19 & 6,357 & 5,852 & 9,964 & 10 & 1 & 4 & 1 & 1 & 8,957 & 11,805 & 7,748 & . & Jo, & 6,641 & 4,953 & 100,1 \\
\hline 1997 & 293 & 456 & 1 & 5,098 & 92 & 2 & 1 & 98 & 18 & 3. & 5 & 29 & 04 & 702 & 555 & 5 \\
\hline 10 & 190 & 447 & 1 & 515 & 47 & 0 & . & 36 & 11,367 & 1. & 036 & 9,016 & 52 & 2,002 & 657 & \\
\hline 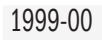 & 617 & 095 & 0 & 885 & 36 & 2 & 2 & 32 & 1 & 1 & 7 & 27 & 64,374 & -668 & 89 & \\
\hline . & ,911 & 200 & 13,735 & 6,129 & 19,319 & 66,294 & 22,852 & 856 & 886 & 11,8 & 519 & 10 & 392 & $-1,902$ & 087 & \\
\hline $010<$ & ,097 & 646 & 13,803 & 7,754 & 2 & ,307 & 24,128 &, 082 & 11,752 & 17,6 & 5 & 7 & 71,932 & -375 & 712 & \\
\hline $2002-03$ & 195 & 59 & 1 & 4 & 2 & 5 & 2 & 0 & 1 & 1 & 4 & 4 & 74,558 & -117 & 95 & 5 \\
\hline 2003-04 & 301 & 58 & 1 & 3 & 39 & 9 & 2 & 1 & 1 & 1 & 28 & 4 & 32 & 33 & & \\
\hline 2 & 320 & 3 & 55 & 82 & 52 & 2 & 3 & 33 & 1 & 52 & 79 & 68 & 47 & 55 & & \\
\hline 2 & 041 & 4 & 54 & 1 & 08 & 8 & 3 & 9,998 & 1 & 2 & 21 & 19 & 0 & 298 & & 1 \\
\hline 2 & 655 & 345 & 228 & 36 & 32,356 & 20 & 3 & 55 & 1 & 2 & 20 & 31 & 51 & $-2,269$ & 066 & 1 \\
\hline 20 & 472 & 990 & 745 & 97 & 311 & 104,115 & 3 & 82 & 2 & 1 & 1 & 14 & $t$ & 0 & 66 & 6 \\
\hline 20 & 738 & 8 & 21 & 1 & 34 & 32 & 4 & 15 & 2 & 1 & 75 & 66 & 1 & 09 & 75 & 5 \\
\hline 20 & 23,421 & 7 & 59 & 20 & 86 & 13 & 4 & 1 & 2 & 2 & 56 & 19 & 5 & 62 & 37 & 7 \\
\hline 20 & 111 & 77 & 13 & 41 & 543 & 1 & 14 & 1 & 2 & & 06 & 80 & 86 & 11 & 48 & 3 \\
\hline 2011-12 & 48 & 44 & 20,159 & 305 & 817 & 773 & 03 & 90 & 721 & ,146 & 0 & 082 & 42 & 669 & 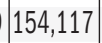 & 7 235,582 \\
\hline
\end{tabular}





\title{
ABOUT THE SCHOOL OF PUBLIC POLICY
}

The School of Public Policy will become the flagship school of its kind in Canada by providing a practical, global and focused perspective on public policy analysis and practice in areas of energy and environmental policy, international policy and economic and social policy that is unique in Canada.

The mission of The School of Public Policy is to strengthen Canada's public service, institutions and economic performance for the betterment of our families, communities and country. We do this by:

- Building capacity in Government through the formal training of public servants in degree and non-degree programs, giving the people charged with making public policy work for Canada the hands-on expertise to represent our vital interests both here and abroad;

- Improving Public Policy Discourse outside Government through executive and strategic assessment programs, building a stronger understanding of what makes public policy work for those outside of the public sector and helps everyday Canadians make informed decisions on the politics that will shape their futures;

- Providing a Global Perspective on Public Policy Research through international collaborations, education, and community outreach programs, bringing global best practices to bear on Canadian public policy, resulting in decisions that benefit all people for the long term, not a few people for the short term.

\author{
The School of Public Policy \\ University of Calgary, Downtown Campus \\ 906 8th Avenue S.W., 5th Floor \\ Calgary, Alberta T2P $1 \mathrm{H} 9$ \\ Phone: 4032107100
}

\section{DISTRIBUTION}

Our publications are available online at www.policyschool.ca.

\section{DISCLAIMER}

The opinions expressed in these publications are the authors' alone and therefore do not necessarily reflect the opinions of the supporters, staff, or boards of The School of Public Policy.

\section{COPYRIGHT}

Copyright (C) 2014 by The School of Public Policy.

All rights reserved. No part of this publication may be reproduced in any manner whatsoever without written permission except in the case of brief passages quoted in critical articles and reviews.

\section{DATE OF ISSUE}

July 2014

\section{MEDIA INQUIRIES AND INFORMATION}

For media inquiries, please contact Morten Paulsen at 403-453-0062.

Our web site, www.policyschool.ca, contains more information about The School's events, publications, and staff.

\section{DEVELOPMENT}

For information about contributing to The School of Public Policy, please contact Courtney Murphy by telephone at $403-210-7201$ or by e-mail at cdmurphy@ucalgary.ca.

\section{ISSN}




\section{RECENT PUBLICATIONS BY THE SCHOOL OF PUBLIC POLICY}

FROM TRIAL TO TRIUMPH: HOW CANADA'S PAST FINANCIAL CRISES HELPED SHAPE A SUPERIOR REGULATORY SYSTEM

http://policyschool.ucalgary.ca/sites/default/files/research/savage-financeevol.pdf

Lawrie Savage | May 2014

THE FREE RIDE IS OVER: WHY CITIES, AND CITIZENS, MUST START PAYING FOR MUCH-NEEDED INFRASTRUCTURE

http://policyschool.ucalgary.ca/sites/default/files/bazelmintz-urban-growth.pdf

Philip Bazel and Jack Mintz | May 2014

ALBERTA CITIES AT THE CROSSROADS: URBAN DEVELOPMENT CHALLENGES AND OPPORTUNITIES IN HISTORICAL AND COMPARATIVE PERSPECTIVE http://policyschool.ucalgary.ca/sites/default/files/research/taylor-ab-cities-5.pdf

Anna Kramer, Marcy Burchfield and Zack Taylor | May 2014

ONTARIO'S EXPERIMENT WITH PRIMARY CARE REFORM

http://policyschool.ucalgary.ca/sites/default/files/ontario-health-care-reform.pdf

Gioia Buckley / Arthur Sweetman | May 2014

THE MIDDLE POWER AND THE MIDDLE KINGDOM: SECURING CANADA'S PLACE IN THE NEW CHINA-U.S. ECONOMIC AND STRATEGIC WORLD ORDER http://policyschool.ucalgary.ca/sites/default/files/dobson-china-communique.pdf

Wendy Dobson | April 2014

SAFETY IN NUMBERS: EVALUATING CANADIAN RAIL SAFETY DATA

http://policyschool.ucalgary.ca/sites/default/files/research/winter-rail-safety-communique.pdf

Jennifer Winter | April 2014

CHINA'S STATE-OWNED ENTERPRISES AND CANADA'S FDI POLICY

http://policyschool.ucalgary.ca/sites/default/files/research/dobson-china.pdf

Wendy Dobson | March 2014

THE TAMING OF THE SKEW: FACTS ON CANADA'S ENERGY TRADE

http://policyschool.ucalgary.ca/sites/default/files/research/tombe-can-energytrade.pdf

Trevor Tombe | March 2014

CANADA-KOREA FREE TRADE: A WATERSHED IN ECONOMIC INTEGRATION WITH ASIA

http://policyschool.ucalgary.ca/sites/default/files/research/canada-korea-trade.pdf

Eugene Beaulieu | March 2014

KEEPING THE GENIE IN THE BOTILE: GRADING THE REGULATION OF CANADIAN FINANCIAL INSTITUTIONS

http://policyschool.ucalgary.ca/sites/default/files/research/chant-financial-regulation-final.pdf

John Chant | March 2014

SIMULATED REPLACEMENT RATES FOR CPP REFORM OPTIONS

http://policyschool.ucalgary.ca/sites/default/files/research/milligan-cpp-options-final.pdf

Kevin Milligan and Tammy Schirle | March 2014

ABORIGINAL-CANADIANS AND ENERGY LITERACY: A SURVEY OF OPINIONS AND THOUGHTS ON ENERGY

http://policyschool.ucalgary.ca/sites/default/files/research/aboriginal-energy-literacy.pdf

Michal C. Moore, André Turcotte and Jennifer Winter | February 2014

THE RISE AND FALL OF SOCIAL ASSISTANCE USE IN CANADA, 1969-2012

http://policyschool.ucalgary.ca/sites/default/files/research/kneebone-white-social-assistance.pdf

Ron Kneebone and Katherine White | February 2014 